Vol. 8, Issue 10, October 2021

DOI: $10.17148 /$ IARJSET.2021.81023

\title{
Comparative modelling and simulation of Replication Initiation Protein in Banana Bunchy Top Virus
}

\author{
Alagumeena $\mathrm{S}^{\mathbf{1}}$, Harishchander $\mathrm{A}^{\mathbf{2}}$, Aarthi Rashmi $\mathrm{B}^{3}$ \\ ${ }^{1} \mathrm{PG}$ - Department of Bioinformatics, Sri Krishna Arts and Science College, Coimbatore, Tamil Nadu, India-641038 \\ ${ }^{2}$ Assistant professor, Centre for Excellence in Computational Engineering and Networking, \\ Amrita Vishwa Vidyapeetham, Coimbatore, Tamil Nadu, India. \\ ${ }^{3}$ Assistant professor, Department of Bioinformatics, Sri Krishna Arts and Science College, \\ Coimbatore, Tamil Nadu, India-641038
}

\begin{abstract}
Banana Bunchy Top Disease is one of the most severe disease in banana. It is caused by Banana Bunchy Top Virus. The disease is highly prevalent in Africa and Asia. The virus is transmitted by some kind of sources. One of the main source of transmission is through banana aphid - the Pentalonia nigronervosa. The vector is globally distributed and transmits the virus. The virus also spreads through contaminated planting material, and it is also found that all banana cultivars were vulnerable due to a lack of known resistance sources. The symptoms of bunchy top of banana are unique and easily recognised from those produced by other banana viruses. Plants that have been infected have a 'bunchy top' look and rosette appearance. Plants that have been affected do not recover or revive. The virus has a multi-component genome made up of at least six circular DNA segments, single stranded DNA (ssDNA) components ranging in length from 1000 to 1100 nucleotides. Because the 3D structure of the proteins linked with BBTV has yet to be established by experimental approaches, we projected the protein structure using comparative modelling. The research focusses on comparative modelling and simulation of replication initiation protein in Banana Bunchy Top Virus.
\end{abstract}

Keywords : BBTD, BBTV, Pentalonia nigronervosa, Bunchy top, Rosette appearance and Comparative modelling.

\section{INTRODUCTION}

Banana belongs to the family Musaseae. It is one of the most important fruits cultivated and consumed. It is being cultivated for two main reasons: 1. Food, 2.Fibre for Textile industry. Each and every part of the plant has its own value and uses. The plant gets diseased and infected by various sources. One among those diseases is BBTD (Banana Bunchy Top Disease). This disease is caused by a virus named BBTV (Banana Bunchy Top Virus).

There is no control measures to control BBTV. Once after it gets infested in the field, the plant won't grow well. It will express rosette appearance (Figure 3,4) and stunted growth. This is the epic and most unique symptom of BBTV attack. Main reason for the transmission of the virus is Banana Aphid, Pentalonia nigronervosa. Control of the aphids is only a preventive measure. There's no post attack management for this BBTD. So focussing on comparative modelling and simulation of replication initiation protein in Banana Bunchy Top Virus is very important because the attack of BBTV causes more economical loss to the farmer and there is no chance for the crop to get revived to normal stage after infection. 


\section{HEALTHY BANANA PLANT}

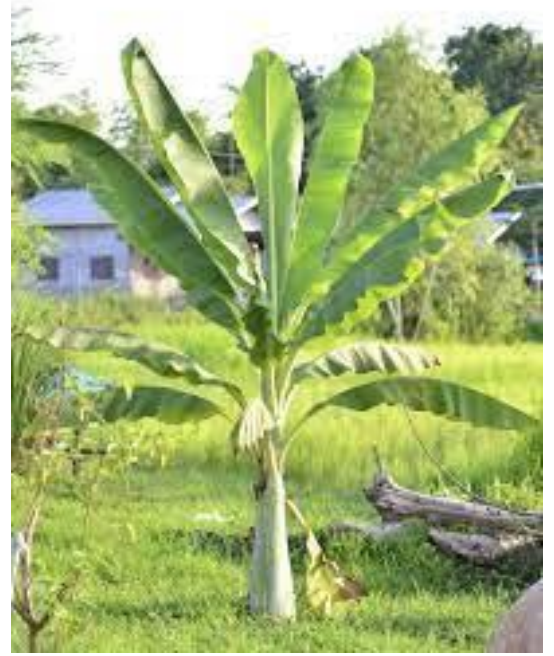

Figure 1

ROSETTE APPEARANCE

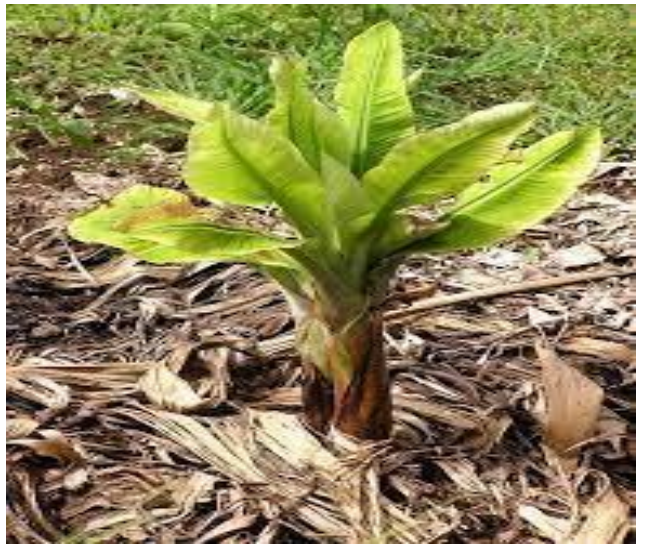

Figure 3

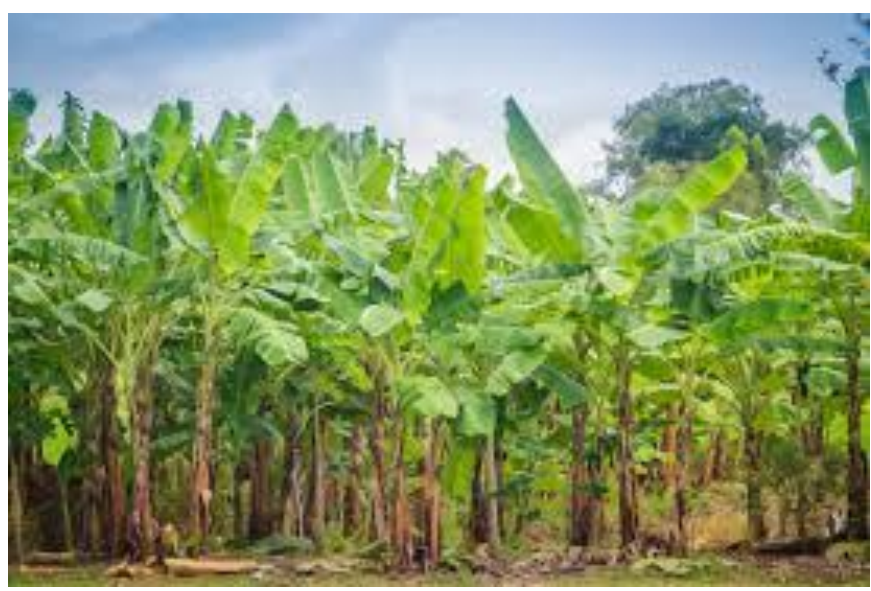

Figure 2

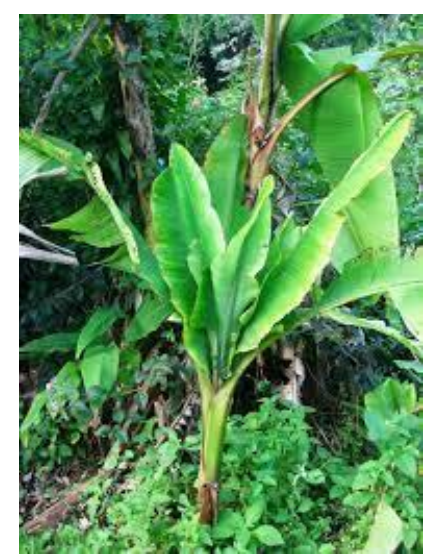

Figure 4

BBTV taxonomic tree

- Domain: Virus

- Group: "ssDNA viruses"

- Family: Nanoviridae

- Genus: Babuvirus

- Species: Banana bunchy top virus

Banana aphid taxonomic tree

- Domain: Eukaryota

- $\quad$ Kingdom: Metazoa

- $\quad$ Phylum: Arthropoda

- Subphylum: Uniramia

- Class: Insecta

- $\quad$ Order: Hemiptera

- $\quad$ Suborder: Sternorrhyncha

- Family: Aphididae

- Genus: Pentalonia

- $\quad$ Species: Pentalonia nigronervosa 
International Advanced Research Journal in Science, Engineering and Technology

Vol. 8, Issue 10, October 2021

DOI: $10.17148 /$ IARJSET.2021.81023

METHODOLOGY

- $\quad$ Protein Modeling:

Template-based modeling (TBM) is a structure prediction approach that uses homologous proteins as templates in this context.

Computational Screening of Leads:

The web server MTiOpen Screen comprises two services, MTiAutoDock and MTiOpen Screen. MTiAutoDock supports docking compounds into a pre- determined or a user-defined binding site and a rigid docking with Autodock 4.2. MTiOpen Screen automates virtual screening by docking with Autodock Vina.

Process

- $\quad$ Step 1: Finding details for Banana Bunchy Top Virus in NCBI.

- $\quad$ Step 2: Search for FASTA Sequence of protein.

- $\quad$ Step 3: Copy the FASTA Sequence.

- $\quad$ Step 4: Paste the FASTA Sequence in SWISS MODEL to develop a model for the sequence identified.

- $\quad$ Step 5: Download the predicted models from SWISS MODEL.

- Step 6: View the downloaded structures in RasMol.

- Step 7: Check the quality of the structures in Ramachandran Plot.

- Step 8: Perform docking using MTiOpen Screen

\section{RESULTS}

The Rampage server's target protein quality provided knowledge of non-bonding interactions between the protein and the ligands (Figure - 5, 6, 7) to determine their binding free energy. This MTi automated docking research identified 7176 compounds in the drug library and the best fit of 1500 molecules. The protein had the most excellent relationship for the Mk3207 chemical, with a $-11.3 \mathrm{Kcal} / \mathrm{mol}$ binding energy. Because of the reduced binding energy, the ligand is more stable than another molecule. Figure 8 gives the details regarding the DNA Sequence of BBTV. Figure 9 showcases the test results made on the transmission of BBTV through Aphids.

\section{PREDICTED STRUCTURAL ORIENTATIONS OF REPLICATION INITIATION PROTEIN}

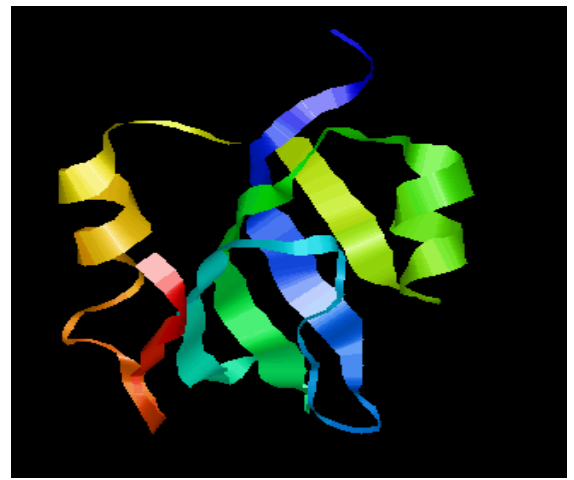

FIGURE 5

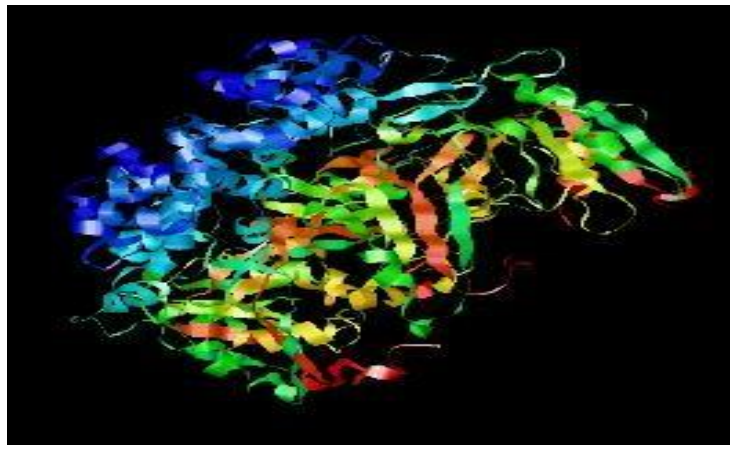

FIGURE 6

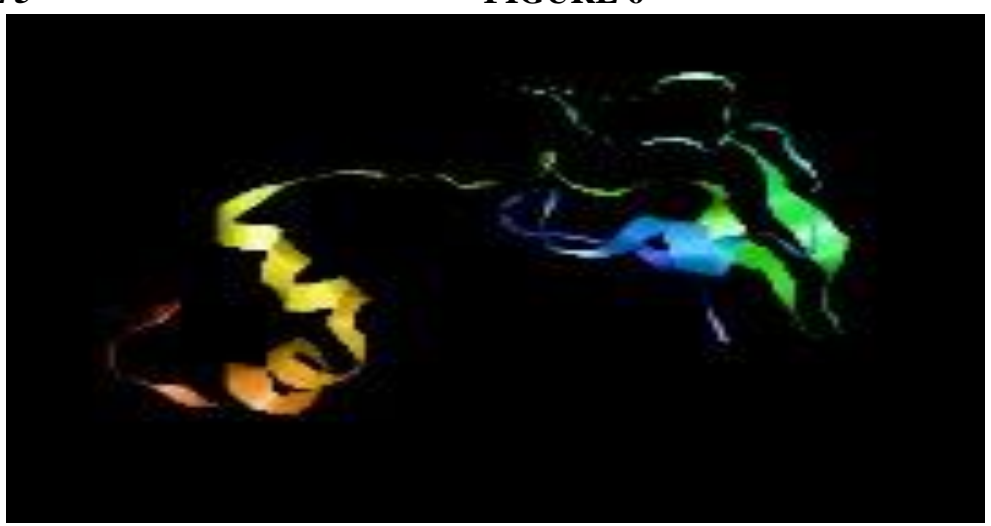

FIGURE 7 


\section{International Advanced Research Journal in Science, Engineering and Technology}

Vol. 8, Issue 10, October 2021

DOI: $10.17148 /$ IARJSET.2021.81023

\begin{tabular}{|c|c|c|c|}
\hline $\begin{array}{l}\text { BBTV } \\
\text { DNA- }\end{array}$ & Primer name & Sequence & Location \\
\hline \multirow[t]{2}{*}{1} & BT1RepEx & $5^{\prime}$ GATCGCGCGATATGTGG $3^{\prime}$ & $129-144$ \\
\hline & BTRepFD & $5^{\prime}$ GAGCTCTCAGCAAGAAACCAAC $3^{\prime}$ & $989-974$ \\
\hline \multirow[t]{2}{*}{2} & BT2R3 & $5^{\prime}$ CCTAATCCTGTCAAGGA $3^{\prime}$ & $266-282$ \\
\hline & BT2F3 & $5^{\prime}$ CGTTAGTATACGTTCCC $3^{\prime}$ & $574-558$ \\
\hline \multirow[t]{2}{*}{3} & BT3V.Exp & $5^{\prime}$ TAGATCCATGGTCAGACAAGAA $3^{\prime}$ & $206-229$ \\
\hline & BT3C.Exp & $5^{\prime}$ ATAAAGCTTTCAAACATGATATGT $3^{\prime}$ & $749-726$ \\
\hline \multirow[t]{2}{*}{4} & BT4V.V3 & $5^{\prime}$ ATCGCATTAACAACACA $3^{\prime}$ & $279-295$ \\
\hline & BT4C.C2 & $5^{\prime}$ GAACATAGGTCCAGCGT $3^{\prime}$ & $629-613$ \\
\hline \multirow[t]{2}{*}{5} & BT5V.Exp & $5^{\prime}$ AAGAGCCATGGAGTTCTGGGAATC $3^{\prime}$ & $233-256$ \\
\hline & BT5C.Exp & $5^{\prime}$ GATATAAGCTTAGACTTAATCTTAC $3^{\prime}$ & $734-711$ \\
\hline \multirow[t]{2}{*}{6} & BTP2B2.17 & $5^{\prime}$ GATCTATTGAAGCTGTG $3^{\prime}$ & $426-442$ \\
\hline & BTP2R1.17 & $5^{\prime}$ CTAACTTCCATGTCTCT $3^{\prime}$ & $666-651$ \\
\hline
\end{tabular}

FIGURE 8

\begin{tabular}{cccc}
\hline $\begin{array}{c}\text { No infective } \\
\text { aphids }\end{array}$ & $\begin{array}{c}\text { No. plants } \\
\text { tested }(n)\end{array}$ & $\begin{array}{c}\text { No, plants } \\
\text { infected }\end{array}$ & $\begin{array}{c}\text { Mean \% } \\
\text { transmission }\end{array}$ \\
\hline 0 & 52 & 7 & 13.5 \\
1 & 9 & 3 & 33.3 \\
2 & 11 & 4 & 36.4 \\
3 & 6 & 4 & 66.7 \\
4 & 31 & 23 & 74.2 \\
5 & 72 & 60 & 83.3 \\
\hline
\end{tabular}

At the end of the LAP, five aphids per group were tested for BBTV. This represents the number of aphids that tested positive for BBTV.

FIGURE 9

\section{CONCLUSION}

Banana is a cash crop in tropical climate which yields more and brings good profit to the farmer who is cultivating it. If this BBTV attacks one banana plant or tree, it will quickly spread its infection to the whole field and there is no management to control the spread. So identifying the replication initiation protein structure is very important for silencing it and for future drug discovery purposes.

\section{REFERENCE}

[1] Su, H. J., Tsao, L. Y., Wu, M. L., \& Hung, T. H. (2003). Biological and molecular categorization of strains of Banana bunch top virus. Journal of Phytopathology, 151, 290-296.

[2] Magee, C. J. P. (1940). Transmission studies on the Banana bunchy top virus. The Journal of the Australian Institute of Agricultural Science, 6 , $109-110$.

[3] Farkas, G. L., \& Kiraly, Z. (1962). Role of phenolic compounds in the physiology of plant disease resistance. Phytopathology, 44, 105-150.

[4] Dietzgen, R. G., \& Thomas, J. E. (1991). Properties of virus-like particles associated with banana bunchy top disease in Hawaii, Indonesia and Tonga. Australasian Plant Pathology, 20, 161-165.

[5] Baker, B., Zambryski, P., Staskaawicz, B., \& Dineshkumar, S. P. (1997). Signaling in plant-microbe interaction. Science, 276, 726-733.

[6] Harishchander A, Anand DA, Computational approach for identifying therapeutic micro RNAs. Int J. Pharm. Pharm Sci. 2014; 6:638-640.

[7] Morris G.M, Huey R, Lindstrom W, Sanner M.F, Belew R.K, Goodsell D.S, Olson A.J.AutoDock4 and AutoDockTools4: automated docking with selective receptor flexibility. J. Comput. Chem. 2009; 30: 2785-2791.

[8] Trott O, Olson A.J. AutoDock Vina: improving the speed and accuracy of docking with a new scoring function, efficient optimization, and multithreading. J. Comput. Chem. 2010; 31: 455-461.

[9] Sharma N K, Jha K K, Priyanka. Molecular docking: an overview J. Adv. Sci.Res. 2010; 67-72

[10] Andrew C Wallace, Roman A Laskowski, Janet M Thornton, Protein Engineering, Design and Selection.1995; 8:127-134.

[11] Dale, J. L., Phillips, D. A., \& Parry, J.N. (1986). Double-stranded RNA in banana plants with bunchy top disease. Journal of General Virology, 67(2), 371-375.

[12] Foottit, R. G., Maw, H. E. L., Pike, K. S., \& Miller, R. H. (2010). The identity of Pentalonia nigronervosa Coquerel and P. Caladii van der Goot (Hemiptera: Aphididae) based on molecular and morphometric analysis. Zootaxa, 2358, 25-38.

[13] Gondwe, W. T., Mwenebanda, B. M. L., Natha, E., \& Mutale, P. (2007). Banana bunchy top disease in Mozambique and Zambia. Infomusa, $16(1 / 2), 38-39$.

[14] Hu, J. S., Wang, M., Sether, D., Xie, W., \& Leonhardt, K. W. (1996). Use of polymerase chain reaction (PCR) to study transmission of banana bunchy top virus by the banana aphid (Pentalonia nigronervosa). Annals of Applied Biology, 128(1), 55-64.

[15] Jooste, A. E. C., Wessels, N., \& van der Merwe, M. (2016). First report of banana bunchy top virus in banana (Musa spp.) from South Africa. Plant Disease, 100(6), 1251.

[16] Kumar, P. L., Hanna, R., Alabi, O. J.,Soko, M. M., Oben, T. T., Vangu, G. H. P., \& Naidu, R. A. (2011). Banana bunchy top virus in sub-Saharan Africa: Investigations on virus distribution and diversity. Virus Research, 159(2), 171-182.

[17] Watanabe, S., Greenwell, A. M., \& Bressan, A. (2013). Localization, concentration, and transmission efficiency of banana bunchy top virus in four asexual lineages of Pentalonia aphids. Viruses, 5(2), 758-776. 